\title{
PENGARUH DEVIDEND PER SHARE DAN EARNING PER SHARE TERHADAP HARGA SAHAMPADA PERUSAHAAN GO PUBLIC DI BURSA EFEK INDONESIA
}

\author{
Christian V. Datu ${ }^{1}$, Djeini Maredesa ${ }^{2}$ \\ ${ }^{1,2}$ Fakultas Ekonomi dan Bisnis, Jurusan Akuntansi, Universitas Sam Ratulangi, Jl. Kampus Bahu, Manado, \\ 95115, Indonesia \\ e-mail: itho.cd@gmail.com
}

\begin{abstract}
Rising share price means increases the value of a company. The company can hold and invest the revenues from on pay dividend shareholders, this can be harmful to shareholders that require that the information is the main thing that EPS need to be noted and made measure that better by investors in making a decision to invest, so that it will affect the demand for the corresponding company shares which in the end will affect the share price, where when investors consider EPS companies good enough and will produce a return in accordance with the risk that will be borne our griefs, then the demand for the shares of the company will increase, which means the company share price will also increase.
\end{abstract}

Keywords : Dividends Per Share, Earning per Share (EPS), Share Price

\section{PENDAHULUAN}

Semakin terbukanya perekonomian Indonesia terhadap perekonomian dunia, perkembangan dunia usaha di tanah air mengalami kemajuan yang cukup pesat. Hal ini dapat dilihat dari semakin banyaknya perusahaan dan lembaga keuangan yang didirikan dalam rangka menyemarakan dan mendukung kegiatan perekonomian di tanah air. Pasar modal dipandang sebagai salah satu sarana alternatif untukmempercepat pembangunan suatu negara. Hal ini dimungkinkan karena pasar modal merupakan wahana yang dapat menggalang pergerakan dana jangka panjang dari masyarakat untuk disalurkan ke sektor-sektor produktif. Apabila pergerakan dana dari masyarakat melalui lembaga-lembaga keuangan maupun pasar modal sudah dapat berjalan dengan baik, maka dana pembangunan yang bersumber dari luar negeri semakin lama semakin di kurangi. Pasar modal yang diyakini sebagai wahana penghimpunan dana-dana jangka panjang merupakan alternatif sebagai sumber dana bagi perusahaan swasta, BUMN, maupun perusahaan daerah.

Melalui pasar modal diharapkan dapat meratakan hasil pembangunan melalui pemilikan saham-saham perusahaan swasta serta penyediaan lapangan kerja dan pemerataan kesempatan berusaha. Menarik dana dari masyarakat untuk berpartisipasi dalam pemilikan saham-saham perusahaan yang sudah memasyarakat atau lebih dikenal dengan istilah " $g o$ public" melalui pasar modal (Bursa Efek Indonesia), harapannya adalah agar saham-saham perusahaan tersebut dapat memberikan penghasilan yang tinggi bagi mereka yang memilikinya karena hanya dengan demikian surat berharga jadi menarik bagi para investor, setidaknya hasil yang diperoleh sama atau lebih besar dari pada pendapatan hasil menabung di bank-bank pada umumnya, maka kecenderungan untuk membeli saham dan bermain di pasar modal mulai digairahkan.

Persoalan yang timbul adalah sejauh mana perusahaan mampu mempengaruhi harga saham di pasar modal dan faktor atau variabel apa sajakah yang dapat dijadikan indikator, sehingga memungkinkan perusahaan untuk mengendalikannya, dan tujuan meningkatkan nilai perusahaan melalui nilai saham yang diperdagangkan di pasar modal tercapai. Investor yang berinvestasi di pasar modal memerlukan pertimbangan-pertimbangan yang matang informasi yang akurat yang diperlukan yaitu mengetahui sejauh mana eratnya hubungan variabel-variabel yang menjadi penyebab fluktuasi harga saham perusahaan yang akan dibeli. 
Dengan mengetahui pengaruh-pengaruh variabel tersebut,investor dapat memiliki strategi untuk memilih perusahaan yang benar-benar dianggap sehati sebagai tempat menanamkan modalnya.

Mengingat pemegang saham yang dapat berpindah-pindah perusahaan, sebuah yang dapat mengubah satu kebijakan pembayaran dividen ke kebijakan yang lainnya dapat membiarkan pemegang saham yang tidak menyukai kebijakan tersebut menjual sahamnya kepada investor lain yang menyukainya. Namun, demikian pula peluang investasi enggan memperhatikan hal ini saja, perusahaan harus mengubah dividen mereka sewaktu-waktu, menaikannya sewaktu arus kas besar dan kebutuhan dana akan relatif kecil, dan menurunkannya jika persediaan uang kas menipis, dalam kaitannya dengan peluang investasi. Akan tetapi, banyak pemegang saham mengandalkan dividen untuk membayar berbagai biaya, dan mereka akan sangat terganggu jika aliran dividen tidak stabil, selanjutnya, tindakan mengurangi dividen agar dana tersedia untuk investasi modal dapat mengirimkan isyarat yang tidak tepat, dan hal itu bisa menurunkan harga saham. Jadi, memaksimumkan hargas aham mengharuskan perusahaan menyeimbangkan kebutuhan dana untuk internal dan keinginan para pemegang saham. Perusahaan denganlaba dan arus kas yang mudah berubah enggan membuat komitmen untukmeningkatkan dividen setiap tahun. Tujuan dilakukan penelitian ini adalah untuk mengetahui pengaruh dari variabel deviden per share dan variabel earning per share terhadap harga saham perusahaan go public di Bursa Efek Indonesia, baik secara bersama-sama maupun individu.

\section{TINJAUAN PUSTAKA}

\subsection{Pengertian Saham}

Menurut Darmadji dan Fakhruddin (2006:6), saham (stock atau share) dapat didefinisikan sebagai tanda penyertaan atau pemilikan seseorang atau badan hukum dalam suatu perusahaan atau perseroan terbatas. Dengan memiliki saham suatu perusahaan maka manfaat yangdiperoleh adalah:

a) Dividen (dividend), yaitu bagian dari keuntungan perusahaan yang dibagikan kepada para pemegang saham.

b) Perolehan modal (capital gain), yaitu keuntungan yang diperoleh dari selisih harga jual dengan harga beli saham.

c) Manfaat bukan finansial, yaitu timbulnya kebanggaan dan kekuasaan memperoleh hak suara dalam menentukan jalannya perusahaan.

\subsection{Harga Saham}

Harga saham adalah harga pasar atau sekuritas saham yang terjadi karenaadanya interaksi antara permintaan dan penawaran pasar, yang secara dasarditentukan oleh aktiva yang diwakilinya. Pada pasar yang efisien, harga sahamberubah berdasarkan informasi yang ada. Dalam persaingan pasar seperti di BursaEfek Indonesia interaksi yang terjadi antara pembeli dan penjual menghasilkan hargapada tingkat keseimbangan (equilibrium price) atau yang biasa disebut jugadengan istilah market value. Harga pasar saham yang aktif diperdagangkan dapatdilihat di surat kabar. Harga penutupan (closing price) menunjukkan harga pasarsaham (market value) pada akhir hari diperdagangkan. Menurut teori Miller dan Modigliani perubahan harga saham dapat dilihatdi sekitar tanggal ex-dividend, yang menyatakan harga saham suatu perusahaanakan turun sebesar dividen yang dibagikan. Tapi para spekulan akan membelisaham sehari sebelum tanggal ex-dividend dan menjual pada tanggal ex-dividenddengan harapan harga saham setelah tanggal ex-dividend tidak turun, sehinggaspekulan tersebut akan menerima dividen dan capital gain.

\subsection{Konsep Dividen dan Jenisnya}

Gallagher dan Andrew (2003:462) dalam Taranika Intan (2009:20) mengartikan dividen yaitu "dividends are the cash payment that corporations make to their common 
stockholders." Stice et al (2004:902) menyatakan bahwa "dividen adalah pembagian kepada pemegang saham dari suatu perusahaan secara proporsional sesuai dengan jumlah lembar saham yang dipegang oleh masing-masing pemilik."

Ada beberapa jenis dividen:

a. Dividen Kas atau Dividen Tunai (cash dividend) yaitu suatu dividen yangdibayarkan dengan uang tunai, atau lebih kerapkali terjadi, dengan cek yangsegera dapat ditukarkan dengan uang tunai. Ini adalah cara yang biasamengenai pembayaran dividen.

b. Dividen Properti atau dividen dalam bentuk harta benda (property dividend)adalah suatu dividen yang terdiri atas suatu bagian dari harta milik perseroanyang dibayarkan kepada para pemegang saham, sebagai ganti uang tunai atausaham perseroan. Ini dapat berupa surat-surat efek atau tanggungan dariperseroan-perseroan lainnya, seperti cabang perseroan, obligasi-obligasipemerintah yang dikuasai, dan lain-lain.

c. Dividen atas surat saham sementara (scrip dividend) yaitu suatu dividen yangdibayarkan dalam skrip, atau dengan perkataan lain, dalam suatu promissorynote, yang harus dibayarkan pada suatu waktu tertentu di kemudian hari. Jadi,ini adalah suatu bentuk deferred dividend (dividen yang ditangguhkan).

d. Dividen Likuidasi (liquidating dividend) adalah suatu dividen yangdibayarkan dari aktiva, kepada para pemilik suatu perseroan yang dibubarkan,atau kepada para kreditur suatu maskapai yang dilikuidir, atau dalam keadaanbangkrut, atau kepada para ahli waris suatu warisan yang sedang diselesaikan. Pembayaran seperti itu dapat terjadi apabila suatu perusahaan jatuh bangkrut atau apabila manajemen memutuskan untuk menjual aktiva perusahaan dan hasilnya didistribusikan kepada para pemegang saham.

e. Dividen Saham (stock dividend) adalah suatu dividen yang dibayarkan dalambentuk saham perseroan itu, bukan dengan uang tunai. Dividen Saham dapatberupa saham tambahan dalam perusahaan atau saham anak perusahaan yangdidistribusikan kepada para pemegang saham.

\subsection{Pengertian Kebijakan Dividen}

Kebijakan dividen merupakan bagian yang tidak dapat dipisahkan dengan keputusan pendanaan perusahaan. Kebijakan dividen merupakan keputusan apakah laba yang diperoleh perusahaan pada akhir tahun akan di bagi kepada pemegang saham dalam bentuk dividen atau akan ditahan untuk menambah modal guna pembiayaan investasi dimasa yang akan datang. Rasio pembayaran dividen menentukan pendanaan. Rasio ini menunjukan persentase laba perusahaan yang dibayarkan kepada pemegang saham biasa perusahaan berupa dividen kas. Apabila laba perusahaan yang ditahan dalam jumlah besar, berarti laba yang akan dibayarkan sebagai dividen menjadi lebih kecil. Dengan demikian aspek penting dari kebijakan dividen adalah menentukan alokasi laba yang sesuai diantara pembayaran laba sebagai dividen dengan laba yang ditahan di perusahaan.

\subsection{Faktor-Faktor Yang Mempengaruhi Harga Saham}

Menurut Weston dan Brigham ( 2001:26 ), factor-faktor yang mempengaruhi harga saham adalah :

1. Laba per lembar saham (Earning Per Share/EPS). Seorang investor yang melakukan invastasi pada perusahaan akan menerima laba atas saham yang dimilikinya. Semakin tinggi laba per lembar saham (EPS) yang diberikan perusahaan akan memberikan pengembalian yang cukup baik. Ini akan mendorong investor untuk melakukan investasi yang lebih besar lagi sehingga harga saham perusahaan akan meningkat.

2. Tingkat Bunga. Tingkat bunga dapat mempengaruhi harga saham dengan cara :

a. Mempengaruhi persaingan di pasar modal antara saham dengan obligasi, apabila suku bunga naik maka investor akan menjual sahamnya untuk ditukarkan dengan obligasi. Hal ini akan menurunkan harga saham. Hal sebaliknya juga akan terjadi apbila tingkat bunga mengalami penurunan. 
b. Mempengaruhi laba perusahaan, hal ini terjadi karena bunga adalah biaya, semakin tinggi suku bunga maka semakin rendah laba perusahaan. Suku bunga juga mempengaruhi kegiatan ekonomi yang juga akan mempengaruhi laba perusahaan.

3. Dividend Per Share (DPS). Kebijakan pembagian dividen dapat dibagi menjadi dua, yaitu sebagian dibagikan dalam bentuk deviden dan sebagian lagi disisihkan sebagai laba ditahan. Sebagai salah satu factor yang mempengaruhi harga saham, maka peningkatan pembagian dividen merupakan salah satu cara untuk meningkatkan kepercayaan dari pemegang saham karena jumlah kas dividen yang besar adalah yang diinginkan oleh investor sehingga harga saham naik.

4. Jumlah laba yang didapat perusahaan Pada umumnya, investor melakukan investasi pada perusahaan yang mempunyai profit yang cukup baik karena menunjukan prospek yang cerah sehingga investor tertarik untuk berinvestasi, yang nantinya akan mempengaruhi harga saham perusahaan

5. Tingkat Resiko dan Pengembalian. Apabila tingkat resiko dan proyeksi laba yang diharapkan perusahaan meningkat maka akan mempengaruhi harga saham perusahaan. Biasanya semakin tinggi resiko maka semakin tinggi pula tingkat pengembalian saham yang diterima.

\subsection{Earning Per Share (EPS)}

Menurut Robbert Angg (1997), EPS merupakan perbandingan antara laba bersih setelah pajak pada suatu tahun buku dengan jumlah saham yang diterbitkan. Di dalam perhitungan EPS, terdapat dua jenis EPS, yaitu :

1. EPS Historis yaitu EPS yang dihitung berdasarkan kinerja perusahaan pada tahun buku yang telah lampau. EPS historis merupakan nilai yang telah terjadi pada masa lampau.

2. EPS Proyektif EPS yang diperkirakan akan terjadi dengan asumsi sesuai dengan proyeksi kinerja emiten.

Earning Per Share(EPS) Menurut Brealy dan Stewart (1986) menyatakan bahwa para penanam modal (investor) sering menggunakan istilah income stock and growth stock. Mereka kelihatannya membeli saham yang sedang tumbuh terutama dengan pengharapan memperoleh keuntungan modal dan mereka lebih berminat pada pertumbuhan pendapatan pada masa mendatang daripada dalam dividen tahun berikutnya. Sebaliknya mereka membeli incomestock terutama untuk memperoleh dividen tunai.

\subsection{Dividend Per Share (DPS)}

Menurut James C. Van Horne dan John M. Wachowicz Jr, (1998) dividen saham hanyalah merupakan pembayaran saham tambahan saham biasa pada pemegang saham. Dividen saham tersebut tidak lebih dari rekapitulasi perusahaan, proporsi kepemilikan dari pemegang saham tetap tidak berubah. Secara teoritis, dividen saham bukan sesuatu yang menyangkut nilai bagi para investor. Mereka menerima sertifikat saham tambahan tetapi kepemilikan proposional mereka atas perusahaan tersebut tidak berubah. Harga pasar saham akan menurun secara proporsional sehingga nilai tunai saham mereka tetap sama. Apabila pemegang saham ingin menjual sahamnya untuk memperoleh penghasilan, maka dividen saham lebih memudahkan penjualan tersebut. Tentunya, tanpa dividen saham para pemegang saham dapat juga menjual sebagian saham mereka untuk memperoleh penghasilan.

Dividend Per Share (DPS) merupakan total semua dividen yang dibagikan pada tahun buku sebelumnya, baik dividen intern, dividen total atau dividen saham (Robbert Ang:1997). Dividen saham merupakan pembayaran tambahan saham biasa kepada pemegang saham. Dividen saham hanya menunjukkan perubahan pembukuan dalam perkiraan ekuitas pemegang saham pada neraca perusahaan. Proporsi kepemilikan saham dalam perusahaan tetap sama. Akuntansi membedakan dividen saham menjadi dividen saham persentase kecil dan dividen persentase besar (James C. Van Horne dan John M. Wachowicz Jr (1998). 


\section{METODE PENELITIAN}

\subsection{Jenis dan Sumber Data}

Jenis data dalam penelitian ini menggunakan data kuantitatif yang diambil dari laporan keuangan tahun 2012 sampai dengan 2017 di 28 perusahaan dengan 84 sampel pengamatanData sekunder merupakan data yang dikumpulkan oleh lembaga pengumpul data dan dipublikasikan kepada masyarakat pengguna data yang didapatkan dari Bursa Efek Indonesia (BEI).

\subsection{Populasi dan Sampel Penelitian}

Menurut Kuncoro (2003: 103) populasi adalah kelompok elemen yang lengkap dimana tertarik untuk mempelajari atau menjadi objek penelitian. Populasi penelitian ini adalah perusahaan Go Public yang terdaftar di BEI yang berjumlah 383 perusahaan. Sampel penelitian ini adalah perusahaan Go Public yang terdaftar di BEI yang berjumlah 28 perusahaan dengan 84 sampel pengamatan.

\subsection{Teknik Analisis Data}

Adapun langkah-langkah yang dilakukan oleh peneliti dalam menganalisa data adalah sebagai berikut :

a. Uji Normalitas

Dalam penelitian, uji normalitas merupakan syarat yang harus dipenuhi untuk suatu model regresi karena model regresi variable bebas dan variable tergantung harus terdistribusi normal. Pengujian normalitas dilakukan untuk mengetahui apakah modelmodel regresi, variable-variabel dependen, variable-variabel independen mempunyai distribusi normal atau tidak. Menurut Ghozali (2006:110), uji normalitas bertujuan untuk menguji apakah dalam model regresi, variabel pengganggu atau residual memiliki distribusi normal.

b. Uji Autokorelasi

Untuk mendeteksi tingkat keeratan suatu hubungan, asumsi ini didefinisikan sebagai terjadinya korelasi di antara dua pengamatan, dimana munculnya suatu data dipengaruhi oleh data sebelumnya. Adanya suatu korelasi bertentangan dengan salah satu asumsinya, artinya jika ada korelasi maka dapat dikatakan bahwa koefisiensi dari persamaan estimasi yang diperoleh kurang kuat. Untuk mengetahui adanya korelasi digunakan uji Durbin Watson yang bisa dilihat dari hasil uji regresi berganda. Secara konvensional dapat dikatakan telah memenuhi asumsi non-autokorelasi jika nilai uji

c. Uji Multikolinearitas

Uji multikolinearitas dilakukan untuk menguji apakah model regresi berganda ditemukan adanya korelasi antar variable bebas. Model regresi yang baik seharusnya tidak terjadi korelasi antara variabel-variabel independennya. Pengujian ada tidaknya multikolinearitas dilihat dari nilai korelasi dua variabel independen tersebut mendekati satu atau nilai korelasi parsial akan mendekati nol, disamping itu juga apabila nilai variance inflation factor (VIF) > 2 maka terjadi multikolinearitas (Cornelius Trihendradi, 2007:14).

d. Uji Heteroskedastisitas

Model regresi akan layak digunakan apabila tidak terdapat heteroskedastisitas. Untuk mendeteksi ada tidaknya heteroskedastisitas dapat digunakan dengan melihat ada atau tidaknya pola tertentu pada grafik plot. Jika terbentuk pola-pola tertentu yang teratur (konstan) maka regresi mengalami heterokedastisitas tetapi jika tidak membentuk suatu pola acak berarti regresi tidak mengalami heteroskedastisitas.(Cornelius Trihendradi, 2007:14). 


\section{HASIL ANALISIS DAN PEMBAHASAN}

\subsection{Hasil Analisis}

Analisis yang digunakan untuk hasil penelitian ini adalah statistik inferen berupa regresi linear berganda yaitu alat analisis peramalan nilai pengaruh dua variabel atau lebih terhadap satu variabel terikat untuk membuktikan ada tidaknya hubungan fungsional atau hubungan kausal antara dua variabel bebas atau lebih dengan satu variabel terikat.

Tabel 4.1

\section{Coefficients}

\begin{tabular}{|ll|r|r|r|r|r|}
\hline \multirow{2}{*}{ Model } & \multicolumn{2}{|c|}{$\begin{array}{c}\text { Unstandardized } \\
\text { Coefficients }\end{array}$} & \multicolumn{2}{c|}{$\begin{array}{c}\text { Standardized } \\
\text { Coefficients }\end{array}$} & \\
\cline { 2 - 5 } & B & \multicolumn{1}{|c|}{ Std. Error } & \multicolumn{1}{|c|}{ Beta } & \multicolumn{1}{c|}{ Sig. } \\
\hline 1 & (Constant) & 3.673 & .340 & & 10.802 & .000 \\
& DPS & .282 & .124 & .339 & 2.268 & .026 \\
& EPS & .514 & .143 & .537 & 3.593 & .001 \\
\hline
\end{tabular}

a. Dependent Variable: Harga.Saham

Sumber; Diolah dari SPSS

Dari hasil pengolahan data dengan SPSS Ver. 15 maka persamaan regresi yang didapat adalah :

$\mathrm{Y}=\alpha+\beta_{1} \mathrm{X}_{1}+\beta_{2} \mathrm{X}_{2}$

$\mathrm{Y}=3,673+0,282 \mathrm{X}_{1}+0,514 \mathrm{X}_{2}$

Dimana implikasi manajerial yang dapat dijelaskan adalah sebagai berikut :

1. Harga Saham akan bernilai 3,673 apabila variabel independen lain adalah konstan.

2. Jika nilai $\beta_{1}$ yang merupakan koefisien korelasi berganda dari variabel dividen pershare $\left(\mathrm{X}_{1}\right)$ sebesar 0,282 mempunyai arti bahwa Harga Saham akan mengalami kenaikan sebesar 0,282 apabila terjadi kenaikan sebesar 1 satuan

3. ika nilai $\beta_{2}$ yang merupakan koefisien korelasi berganda dari variabel earning per share $\left(\mathrm{X}_{2}\right)$ sebesar 0,514 mempunyai arti bahwa Harga Saham akan mengalami kenaikan 0.514 apabila terjadi kenaikan sebesar 1 satuan.

Dengan demikian dapat diketahui bahwa tanda positif yang terdapat pada koefisien regresi berganda dividen pershare $(+0,282)$ dapat diartikan bahwa setiap kali terjadi peningkatan dividen pershare maka akan terjadi peningkatan Harga Saham, begitu juga dengan tanda positif pada koefisien regresi earning per share $(+0,514)$ memberi pengertian bahwa setiap kali terjadi peningkatan earning per share maka akan diikuti oleh peningkatan harga saham.

Berdasarkan Tabel 4.1, maka dapat dilihatbahwadividen pershare $(D P S) \quad\left(\mathrm{X}_{1}\right) \mathrm{t}_{\mathrm{hitung}}=$ 2,262 $>\mathrm{t}_{\text {tabel }} 2,132$ dan tingkat signifikansi $0,026<0,05$, sehingga Ho1 ditolak dan Ha1 diterima atau DPS secara parsial berpengaruh terhadap Harga Saham.

Hal ini sesuai penelitian Tambunan (2007) meneliti pengaruh kebijakan dividen terhadap harga saham pada perusahaan manufaktur di Bursa Efek Jakarta. Penelitian ini menyimpulkan bahwa dividen pershare dan earning per share mempunyai pengaruh positif terhadap harga saham. Raymond (2007) meneliti pengaruh dividen pershare dan earning per share terhadap harga saham pada PT. Telekomunikasi Indonesia Tbk. periode 2002-2006. Berdasarkan analisis yang telah dilakukan dengan analisis regreesi dan korelasi dapat disimpulkan bahwa dividen pershare dan earning per share mempunyai hubungan yang cukup kuat terhadap harga saham.

Dari segi teori,menurut Sharpe dan kawan-kawan (1997) hubungan Dividen pershare (DPS) dengan Harga Saham bahwa perubahan dividen adalah pengumuman kenaikan dividen yang merupakan tanda bahwa manajemen telah menaikkan pendapatan masa depan perusahaan. Oleh karena itu, pengumuman kenaikan dividen merupakan kabar baik dan pada 
gilirannya akan menaikkan ekspektasi mereka mengenai pendapatan perusahaan. Hal ini merupakan suatu implikasi bahwa pengumuman kenaikan dividen akan menyebabkan kenaikan harga saham perusahaan

Berdasarkan Tabel 4.1, maka dapat dilihatbahwaearning per share $(\mathrm{EPS})\left(\mathrm{X}_{2}\right) \mathrm{t}_{\text {hitung }}=$ 3,593> $\mathrm{t}_{\text {tabel }} 2,132$ dan tingkat signifikansi 0,001 <0.05, sehingga Ho2 ditolak dan Ha2 diterima atau EPS secara parsial berpengaruh terhadap Harga Saham.

Hal ini sesuai dengan penelitian yang Sasongko dan Wulandari (2003) melakukan penelitian tentang pengaruh ratio-ratio keuangan terhadap harga saham perusahaan manufaktur yang terdaftar di BEJ tahun 2001-2002. Variable independen yang diteliti yaitu return on assets (ROA), earning per share (EPS), return on sales (ROS), dan basic earning power (BEP). Hasil penelitian menunjukkan bahwa hanya EPS yang berpengaruh terhadap harga saham, sedangkan ROA, ROS, dan BEP tidak berpengaruh terhadap saham.

Dari segi teori, pernyataan diatas didukung oleh Tjiptono Darmadji dan Hendy $M$ (2001) pengertian laba per lembar saham atau EPS yaitu merupakan rasio yang menunjukkan berapa besar keuntungan (laba) yang diperoleh investor atau pemegang saham per lembar sahamnya. Laba merupakan alat ukur utama kesuksesan suatu perusahaan, karena itu para pemodal seringkali memusatkan perhatian pada besarnya earning per share (EPS) dalam melakukan analisis saham. Semakin tinggi nilai EPS tentu saja menggembirakan pemegang saham karena semakin besar laba yang disediakan untuk pemegang saham.

Tabel 4.2

ANOV Ab

\begin{tabular}{|ll|r|r|r|r|r|}
\hline \multicolumn{1}{|c|}{} & \multicolumn{1}{c|}{$\begin{array}{c}\text { Sum of } \\
\text { Model }\end{array}$} & Squares & df & Mean Square & \multicolumn{1}{c|}{ F } & Sig. \\
\hline 1 & Regression & 193.591 & 2 & 96.796 & 116.170 & $.000^{\mathrm{a}}$ \\
& Residual & 67.491 & 81 & .833 & & \\
& Total & 261.082 & 83 & & & \\
\hline
\end{tabular}

a. Predictors: (Constant), EPS, DPS

b. Dependent Variable: Harga.Saham

Berdasarkan Tabel 4.2, maka dapat dilihat bahwa nilai $\mathrm{F}_{\text {hitung }} 116,170>\mathrm{F}_{\text {tabel }} 3,68$ dan tingkat signifikansi $0,000<0,05$, sehingga $\mathrm{Ho} 3$ ditolak dan $\mathrm{Ha} 3$ diterima atau dividen pershare dan earning per share secara simultan berpengaruh terhadap Harga Saham.

Dividen Per Share (DPS) merupakan total semua dividen yang dibagikan pada tahun buku sebelumnya, baik dividen intern, dividen total atau dividen saham (Robbert Ang:1997). Dividen saham merupakan pembayaran tambahan saham biasa kepada pemegang saham. Dividen Per Share(DPS) Dengan Harga Saham Menurut Sharpe dan kawan-kawan (1997), perubahan dividen adalah pengumuman kenaikan dividen yang merupakan tanda bahwa manajemen telah menaikkan pendapatan masa depan perusahaan.

\subsection{Pembahasan}

Dari hasil uji yang dilakukan dengan menggunakan program SPSS version 15, nilai Adjusted R Square sebesar 0,735. Hal ini berarti bahwa 73,5\% variasi atau perubahan dalam harga saham dapat dijelaskan oleh sebab-sebab lain yang tidak dimasukan dalam model penelitian.

Dari hasil penelitian, dapat dilihat bahwa variabel tingkat dividen per lembar saham atau DPS $\left(\mathrm{X}_{1}\right) \mathrm{t}_{\text {hitung }}=2,262>\mathrm{t}_{\text {tabel }} 2,132$ danmemiliki pengaruh yang signifikan terhadap harga saham, sebagaimana ditunjukan oleh angka siknifikansinya sebesar 0,026<0,05 setelah dilakukan uji t. Dari hasil penelitian ini, variabel DPS memiliki koefisien regresi bertanda positif sebesar 0,282, artinya apabila terjadi perubahan variabel DPS sebesar $1 \%$ akan menaikan HS sebesar 0,282 atau 28,2\%. Hal ini berarti bahwa perusahaan yang bisa 
memberikan dividen yang besar, harga sahamnya juga akan meningkat, jika DPStinggi maka dapat meningkatkan harga pasar saham perusahaan. Jadi, DPS berpengaruh terhadap harga saham.

Dari hasil penelitian dapat dilihat bahwa variabel tingkat laba per lembar saham atauEPS $\left(\mathrm{X}_{2}\right) \mathrm{t}_{\mathrm{hitung}}=3,593>\mathrm{t}_{\text {tabel }} 2,132$ dan memiliki pengaruh yang sangat signifikan terhadap harga saham, sebagaimana ditunjukan oleh angka singnifikansinya sebesar 0,001 $<0,05$ setelah dilakukan uji t. Dari hasil penelitian ini, variabel EPS memiliki koefisien regresi bertanda positif sebesar 0,514, artinya bahwa apabila terjadi perubahan variabel EPS sebesar 1\% akan menaikan Harga Saham sebesar 0,514 atau 51,4\%. Hal ini berarti bahwa informasi EPS perusahaan yang terdapat dalam laporan keuangan perusahaan yang dipublikasikan merupakan hal yang utama diperhatikan oleh investor dalam membuat keputusan investasinya, sehingga hal tersebut akan mempengaruhi permintaan harga saham perusahaan yang bersangkutan yang pada akhirnya akan mempengaruhi harga saham, dimana apabila investor menganggap bahwa angka EPS perusahaan cukup baik dan akan menghasilkan return yang sepadan dengan resiko yang ditanggungnya, maka permintaan terhadap saham perusahaan tersebut juga akan meningkat, yang berarti harga saham perusahaan tersebut juga akan meningkat. Hasil penelitian ini sesuai dengan penelitian yang dilakukan oleh Sasongko dan Wulandari (2006) yang menemukan bahwa informasi EPS memiliki pengaruh yang angat signifikan terhadap harga saham.

Hal tersebut juga dibuktikan dengan uji $\mathrm{F}$ dimana $\mathrm{F}_{\text {hitung }}$ sebesar19.694dan tingkat signifikansi 0,000, oleh karena $F_{\text {hitung }} 116,170>F_{\text {tabel }} 3,68$ dan tingkat signifikansi $0,000<0,05$ maka disimpulkanbahwa variabel dividend per share (DPS)dan earning per share (EPS) secara simultanmemiliki pengaruh yang signifikan terhadap harga saham

\section{KESIMPULAN DAN SARAN \\ 5.1. Kesimpulan}

Dari hasil penelitian ini, diperoleh kesimpulan sebagai berikut:

1. DPS memiliki pengaruh yang signifikan terhadap harga saham perusahaan go pubic di Bursa Efek Indonesia, sebagaimana ditunjukan DPS $\left(X_{1}\right) t_{\text {hitung }}=2,262>t_{\text {tabel }} 2,132$ dengan tingkat signifikansinya sebesar $0,026<0,05$ setelah dilakukan uji t maka $\left(\mathrm{H}_{\mathrm{a}} 1\right)$ diterima, sehingga dapat disimpulkan bahwa DPS merupakan salah satu faktor bagi investor dalam membuat keputusan investasinya.

2. EPS memiliki pengaruh yang signifikan terhadap harga saham perusahaan go public di Bursa Efek Indonesia, sebagaimana ditunjukan $\operatorname{EPS}\left(\mathrm{X}_{2}\right) \mathrm{t}_{\text {hitung }}=3,593>\mathrm{t}_{\text {tabel }} 2,132$ signifikanya sebesar $0,001<0,05$ setelah dilakukan uji t maka $\left(\mathrm{H}_{\mathrm{a}} 2\right)$ diterima. Dengan demikian dapat disimpulkan bahwa informasi EPS merupakan hal utama yang perlu diperhatikan dan dijadikan tolak ukur yang lebih baik oleh investor dalam membuat keputusan investasinya, sehingga hal tersebut akan mempengaruhi permintaan terhadap saham perusahaan yang bersangkutan yang pada akhirnya akan mempengaruhi harga saham, dimana apabila investor menganggap EPS perusahaan cukup baik dan akan menghasilkan return yang sepadan dengan resiko yang akan ditanggungnya, maka permintaan terhadap saham perusahaan tersebut akan meningkat, yang berarti harga saham perusahaan tersebut juga akan meningkat.

3. Lewat hasil pengujian dari uji $\mathrm{F}$ yang menyatakan bahwa $\mathrm{H}_{\mathrm{a}} 3$ atau Dividend Per Share (DPS) dan Earning Per Share (EPS) secara simultan (bersama-sama) memiliki pengaruh yang signifikan terhadap harga saham perusahaan go pubic di Bursa Efek Indonesia.

\subsection{Saran}

1. Bagi perusahaan untuk meningkatkan kepercayaan pemegang saham terhadap perusahaan, maka perusahaan harus mampu menunjukan kinerja perusahaan yang bagus 
dan menyampaikan informasi penting yang harus disampaikan oleh perusahaan kepada pemegang saham.

2. Bagi investor dan calon investor untuk mengetahui kinerja perusahaan sebelum melakukan investasi sebaiknya para investor maupun calon investor mencari tau tentang profil perusahaan . Profil perusahaan dapat diperoleh melalui Bursa Efek Indonesia dan Instansi Pemerintah yaitu Bapepeam sebagai pihak yang menentukan kebijakan di Bursa Efek Indonesia dalam menjamin keakuratan data informasi keuangan dan memberikan informasi yang berkualitas dengan sarana teknologi ynag canggi sehingga kualitas laporan keuangan perusahaan lebih akurat dan relevan.

3. Bagi peneliti selanjutnya disarankan untuk menggunakan variabel yang lebih bnyak sehingga hasil yang akan diperoleh lebih akurat dan mempunyai cakupan yang lebih luas. Peneliti selanjutnya diharapkan dapat menggunakan harga saham sebelum dan sesudah closing price atau pun menggunakan harga saham rata-rata.

\section{DAFTAR PUSTAKA}

Aharony dan Itzhak (1989) dalam bukunya Nur Indriyanto (1999) Jurnal Riset Akuntansi. Anoraga, Pandji. 2001. Pengantar Pasar Modal (Edisi Revisi).Rineka Cipta. Jakarta Arikunto, Suharsimi. 2002. Prosedur Penelitian Suatu Pendekatan Praktek Rineka Cipta. Jakarta.

Keown Arthur J. dkk. 2000. Dasar-Dasar Manajemen KeuanganSalemba Emapat. Jakarta

Bursa Efek Indonesia (BEI), IDX Monthly statistics, 2009, agustus.

Darmadji, Tjiptono dan Hendy M Fakhruddin,2006. Pasar Modal Di Indonesia Pendekatan Tanya jawab, PT Salemba Empat, Jakarta

Ghozali, Imam. 2006. Aplikasi Analisis Multivariate dengan Program SPSS. Badan Penerbit Universitas Diponegoro. Semarang.

Hariman 2003. "Analisis Pengaruh Rasio Nilai Buku Per Lembar Saham (pricebook value) dan Rasio Laba Per Lembar Saham (price earning ratio) terhadap harga saham di pasar modal(studi pada perusahaan rokok pt. hm. sampoerna tbk. di bursa efek". Jurnal Ekonomi Perusahaan Vol. 10, NO. 2. EdisiJuni 2003.

Halim, Yuliana, 2007. Pengaruh ROE, NPM, EPS, dan DER terhadap Harga Saham Perusahaan Manufaktur Yang Terdaftar Di BEJ. Universitas Sumatera Utara Medan. Skripsi.

Institute for Economic and Financial Research, 2008, Indonesian Capital Market Directory

Jurusan Akuntansi, Fakultas Ekonomi Universitas Sam Ratulangi Manado, 2004. Buku Panduan Penulisan Skripsi, Manado

Kuncoro, Mudrajad, 2003. Metode Riset intuk Bisnis dan Ekonomi, Erlangga, Jakarta

Modigliani, Miller, 1961. Dividend Policy, Growth and The Valuation of Shares. Journal of Business

Nachrowi, Hardius Usman, 2006. Ekonometrika-Pendekatan Popular dan Praktis Untuk Analisis Ekonomi dan Keuangan, Lembaga Penerbit Fakultas Ekonomi Universitas Indonesia, Jakarta

Hariman 2003. "analisis pengaruh rasio nilai buku per lembar saham (pricebook value) dan rasio laba per lembar saham (price earning ratio) terhadap harga saham di pasar modal(studi pada perusahaan rokok pt. hm. sampoerna tbk. di bursa efek". Jurnal Ekonomi Perusahaan Vol. 10, N0. 2. EdisiJuni 2003.

Nurmala, 2001. "Pengaruh Kebijakan Dividend Terhadap Harga Saham Perusahaan Otomotif di Bursa Efek Jakarta" Mandiri volume 9, Nomor 1, STIE Bina Warga Palembang, Palembang.

Sarwoko. 2005. Dasar - Dasar Ekonometrika Edisi I. Penerbit ANDI. Yogyakarta. 
Sasongko, Noer, Nita Wulandari, 2003. "Pengaruh Eva dan Rasio-Rasio Profitabilitas Terhadap Harga Saham”, Emprika, Volume 19 nomor 1, Universitas Muhammadiyah Surakarta, Surakarta.

Sugiono, 2004. Metode Penelitian Bisnis, CV Alfabeta, Bandung

Suad Husnan, Dasar Teori Portofolio dan Analisis Sekuritas, Edisi 2, AMP YKPN,Yogyakarta,1994.

Tamunan, Roy Agust, 2007. "Pengaruh Kebijakan Dividen Terhadap Harga Saham pada Perusahaan Manufaktur di Bursa Efek Jakarta (BEJ), (Skripsi Akuntansi), UNIKA Santo Tomas, Medan.

Trihendradi, Cornelius. 2007. Kupas Tuntas Analisa Regresi. Penerbit ANDI Yogyakarta. 